\title{
HUMAN RIGHTS BALANCES \\ IN HEALTHCARE FIELD UNDER THE JURISPRUDENCE OF THE EUROPEAN COURT OF HUMAN RIGHTS
}

\section{Senyuta I. Ya.}

\section{INTRODUCTION}

The intertwining of medicine, law, and ethics in medical law creates a synergistic value of parallels that run counter to laws. If to speak about humanity as any human rights activity, it can be shown via the European Court of Human Rights (hereinafter referred to as ECtHR) jurisprudence. This institution is the custodian of the rule of law and constantly seeks balances to ensure human rights. The ECtHR "holds" scales with two bowls, on which the rights and legitimate interests are weighted, and a "master's hand" is required to maintain the balance of justice.

The objective of the research is to uncover several balances using ECtHR jurisprudence, national jurisprudence, and Ukrainian statutory law, to seek the rule of law and to ensure the best interests of the human in the healthcare sector.

Some aspects of health care through the prism of the ECtHR jurisprudence have been researched, in particular by such scholars as J. Balsiene, O. Drozdova, P. J. Carozza ${ }^{1}$, M.J. Curtice, T. Exworthy, N. Hutorova, V. Horodovenko ${ }^{2}$, O. Harasymiv, J. Juskevicius, Y. Kapelanska-Pregowska ${ }^{3}$, S. Matthew ${ }^{4}$, V. Pashkov, P. Rabinovych, J.A. Sweeney, L. Udovyka. The following methods of scientific cognition have been used: formal-logical method (for the analysis of the internal construction of legal regulations); method of legal modeling (with a view to implementing the main balance sheet provisions set out in international standards, in particular, the ECtHR's jurisprudence, which, in accordance

${ }^{1}$ P.G. Carozza, Human Dignity, [in:] D. Shelton (ed.), The Oxford Handbook of International Human Rights Law, Oxford 2015, pp. 345-359.

${ }^{2}$ V. Horodovenko, V. Pashkov, L. Udovyka, Protection of Patients' Rights in the European Court of Human Rights, Wiadomości Lekarskie, 2018/06. Available at: http://wl.medlist.org/ 06-2018-13/

${ }^{3}$ Kapelańska-Pręgowska J. European court of human rights (gc), case of lambert and others v. France, judgment of 5 june 2015, application NO. 46043/14. Comparative Law Review, [S. 1], v. 21, p. 157-174, feb. 2017. ISSN 0866-9449. Available.

${ }^{4}$ S. Matthew, The European Court of Human Rights Margin of Appreciation and the Processes of National Parliaments, Human Rights Law Review 2015, vol. 15, no. 4, pp. 745-774. 
with Art. 17 of the Law of Ukraine "On Enforcement of Judgments and Application of the Jurisprudence of the European Court of Human Rights", is a source of law for Ukraine); method of jurisprudence studying (to summarize the law enforcement practice); and method of law interpreting (to find out the content of the relevant legal regulations).

\section{Balance between protecting the patient's right to life and protecting his or her right to respect for privacy}

Two balances, which reveal the most pressing issues for Ukraine, and given the numerous judgments of the ECtHR, interesting for the European community as well, have been observed under the magnifying glass of the researcher. Among these, there is a balance between protecting the patient's right to life and protecting his or her right to respect for privacy. Therefore, it is necessary to find the balance between Art. 2 and Art. 8 of the Convention for the Protection of Human Rights and Fundamental Freedoms (hereinafter referred to as the Convention), which are of great significance for the healthcare sector.

In the case of Lambert and others v. France (2015) ${ }^{6}$, concerning Art. 2 of the Convention, the ECtHR noted that there was no consensus among member states of the Council of Europe on the authorization to terminate life-sustaining treatment, despite the fact that most states seem to allow it (the ECtHR relied on information from 39 of the 47 member states of the Council of Europe). Thus, given the complexity of the institute for the termination of life from a medical, legal and ethical point of view and the lack of agreement on it by the member states of the Council of Europe, they need to be given some discretion on this matter ${ }^{7}$. However, it should be noted that the concept of freedom of discretion is one of the most controversial and discussed in the ECtHR's jurisprudence, and therefore the limits of such freedom shall be determined on a case-by-case basis ${ }^{8}$.

Although the formalities accompanying cessation of treatment differ for different states, there is consensus on the determining role of the will of

${ }^{5}$ Convention for the protection of human rights and fundamental freedoms as of 04.11.1950 (ratified by Ukraine on 17.07.1997). URL: https://zakon.rada.gov.ua/laws/show/995_004.

${ }^{6}$ ECtHR judgment in the case of "Lambert and Others v. France" as of 15.07.2015. URL: http://hudoc.echr.coe.int/eng?i=001-155352.

${ }^{7}$ Kapelańska-Pręgowska J. European court of human rights (gc), case of lambert and others v. France, judgment of 5 june 2015, application No. 46043/14. Comparative Law Review, [S. 1], v. 21, p. 157-174, feb. 2017. ISSN 0866-9449. Available at: <https://apcz.umk.pl/ czasopisma/index.php/CLR/article/view/CLR.2016.005/10962>. Date accessed: 07 Sep. 2019. doi:http://dx.doi.org/10.12775/CLR.2016.005.

8 S. Matthew, The European Court of Human Rights Margin of Appreciation and the Processes of National Parliaments, Human Rights Law Review 2015, vol. 15, no. 4, pp. 745-774. 
the patient in deciding on the method of expression. Given that the peculiarity of the medical profession is the presence of a sufficiently large number of reasons for possible patient dissatisfaction, even the slightest deviation from the patient's expected results can provoke a conflict situation $^{9}$. States should, therefore, be free to decide not only whether to allow or prohibit the termination of life-supportive treatment and the attendant formalities, but also to establish a balance between the protection of the patient's right to life and the right to respect for his or her private life and personal autonomy. In analyzing the particularities of such a balance, one should also take into account the "meta-concept" of human dignity, which is the source of all human and patient rights, in particular ${ }^{10}$. This concept serves to support the decisive role of the right to respect for privacy and personal autonomy ${ }^{11}$. It follows from the ECtHR's jurisprudence that, despite the "sanctity" of life, in some cases, patient autonomy may prevail in respect of respect for human dignity and freedom, which is "the very essence of the Convention"12.

It is the patient, even in a state where he or she is unable to express his or her will, whose consent should be the essence of the decision-making process in which he or she is the main subject and participant. The Council of Europe "Guidance on decision-making for patients of all ages, at the end of their lives" indicate that the patient is involved in the decisionmaking process through a wish that he or she could have orally expressed to one of the family members or one of the relatives. The ECtHR also notes that, in accordance with the comparative law information provided, in some states, in the absence of a prior order or "biological will", the patient's willful expression of will is established by various means (statements by the legal representative, family, other evidence of the patient's identity, his or her conviction etc).

In such case, the State Council, based on the evidence received, found that they were sufficiently precise to determine Vincent Lumber's desire to

${ }^{9}$ V. Horodovenko, V. Pashkov, L. Udovyka, Protection of Patients' Rights in the European Court of Human Rights, Wiadomości Lekarskie, 2018/06. Available at: http://wl.medlist.org/ 06-2018-13/

${ }^{10}$ P.G. Carozza, Human Dignity, [in:] D. Shelton (ed.), The Oxford Handbook of International Human Rights Law, Oxford 2015, pp. 345-359.

${ }^{11}$ Kapelańska-Pręgowska J. European court of human rights (gc), case of lambert and others v. France, judgment of 5 june 2015, application NO. 46043/14. Comparative Law Review, [S.l.], v. 21, p. 157-174, feb. 2017. ISSN 0866-9449. Available at: <https://apcz.umk.pl/czasopisma/ index.php/CLR/article/view/CLR.2016.005/10962>. Date accessed: 07 Sep. 2019. doi:http://dx.doi.org/10.12775/CLR.2016.005.

${ }^{12}$ ECtHR judgment in the case of "Pretty v. United Kingdom" as of 29.04.2002. URL: http://hudoc.echr.coe.int/eng?i=001-60448. 
discontinue or continue treatment. The Court found the requirements of Art. 2 of the Convention, both the legislative framework provided by the Council of Ministers and the decision-making process that was conducted in good faith in the present case. The ECtHR stated that the domestic authorities, in the light of the discretion afforded them in the present case, adhered to their positive obligations under Art. 2 of the Convention.

This issue has become especially important for Ukraine recently, as on 05.06.2019 the Order of the Ministry of Health of Ukraine "On Approval and Implementation of Medical and Technological Documents on Standardization of Emergency Medical Care” No. 1269 (hereinafter - the $\mathrm{MOH}$ of Ukraine Order 1269), by which the clinical protocol "Emergency medical care: pre-hospital stage” (hereinafter - the New clinical protocol) ${ }^{13}$ was approved, had been adopted. This act introduces into the legal system of Ukraine the principles "Do not resuscitate" and "Preliminary order" for the first time. In Section 4.4. The New clinical protocol stipulates that the patient shall carry one of the following documents or a valid alternative (for example, an identification bracelet indicating the patient's wishes). Let us consider two of the above: 1) the order "Do not resuscitate" defines a ban on cardiopulmonary resuscitation and intubation in a situation of cardiac arrest or its onset in a patient. In foreign practice, this is known by the name: "Do not resuscitate" or "no-code"; 2) Preliminary instructions: a document describing the procedures allowed for the specified medical conditions, including all or only some of the following: what to do at cardiac arrest, whether artificial nutrition is allowed, the desire to be a donor or not, dialysis, and other parameters. This prior instruction may often not apply to urgent or transient medical conditions.

Considering these regulatory transformations, a few points should be outlined:

1) in Art. 52 of the Law of Ukraine "Fundamentals of the legislation of Ukraine on health care" (hereinafter - the Fundamentals) it is guaranteed that medical practitioners are obliged to provide full medical care to the patient who is in an emergency condition, and active measures to maintain the patient's life are stopped in case if a person's condition is defined as irreversible death. Medical practitioners are prohibited from performing

${ }^{13}$ Наказ МО3 України «Про затвердження та впровадження медико-технологічних документів зі стандартизації екстреної медичної допомоги» від 05.06.2019 р. № 1269 . URL: https://moz.gov.ua/article/ministry-mandates/nakaz-moz-ukraini-vid-05062019--1269pro-zatverdzhennja-ta-vprovadzhennja-mediko-tehnologichnih-dokumentiv-zi-standartizaciiekstrenoi-medichnoi-dopomogi (Nakaz MOZ Ukrayiny "Pro zatverdzhennya ta vprovadzhennya medyko-tekhnolohichnykh dokumentiv zi standartyzatsiyi ekstrenoyi medychnoyi dopomohy" vid 05.06.2019 r. № 1269). 
euthanasia, that is, deliberately accelerating the death or killing of a terminally ill patient to end his or her suffering. The New Clinical Protocol appears to be correcting a national approach, which is generally unacceptable because, on the one hand, bylaws are for detailing laws and, on the other, human and citizen rights and freedoms, the guarantees of these rights and freedoms are determined under Sec. 1 Art. 92 of the Constitution of Ukraine, laws;

2) it is important to note that, for example, the analyzed item 4.4 of the New Clinical Protocol refers to different states, namely the USA. In Part 7 of Art. 3 of the Law of Ukraine "On emergency medical care" states that the provision of emergency medical care to a person in an emergency at the scene, during transportation and in a health care facility is carried out in accordance with medical evidence based on clinical protocols and standards of emergency medical care, which approved by the MOH of Ukraine. So, it operates in the space that is the territory of Ukraine, but the text of the normative act refers to another country.

3) considering this difficult regulatory act - the New clinical protocol, it should be emphasized the following: a) $\mathrm{MOH}$ of Ukraine order 1269 repealed the orders of the $\mathrm{MOH}$ of Ukraine No. 437 of 31.08.2004 and No. 34 of 15.01.2014, which standardized the provision of emergency medical care in Ukraine, and the New clinical protocol will come into force; b) the New clinical protocol stipulates that the clinical guidelines of the NASEMSO are optional and are not intended to be inclusive or to determine local practice. They are a set of clinical guidelines that can be used as such or adapted for use at the state, regional or local levels to increase the level of patient care and orientation of emergency medical care practices. However, they are obligatory for Ukraine, since they are approved by the MOH of Ukraine Order 1269 and therefore are a by-law; c) given the regulatory definition of the legal framework, "new clinical protocol for medical care", the New clinical protocol is not subject to adaptation, so it is not surprising that the US protocol was not adapted but simply translated, but it is striking that in Ukraine the normative document, which instead of Ukraine and its regions, refers to the US states will be enforceable. And, of course, we should not forget that the new clinical protocol of medical care is obligatory for application in the case of absence of a unified clinical protocol of medical care in the same disease, provided that such clinical protocol is translated into Ukrainian and approved by the $\mathrm{MOH}$ of Ukraine, as clearly stated in item 4 of the $\mathrm{MOH}$ of Ukraine Order "On Amendments to the $\mathrm{MOH}$ of Ukraine Order as of September 28, 2012 No. 751” as of December 29, 2016 No. 1422. 
As mentioned above, the $\mathrm{MOH}$ of Ukraine abolished all unified protocols by of the MOH of Ukraine Order No. 1269.

4) the institute of "preliminary disposition" is also enshrined in the Convention for the Protection of Human Rights and Dignity in the Application of Biology and Medicine: the Convention on Human Rights and Biomedicine ${ }^{14}$, namely Art. 9 regulates the peculiarities of implementation of previously expressed wishes. If at the time of the intervention, the patient is unable to express his or her wishes, the wishes for medical intervention previously expressed by him/her shall be taken into account. It should also be noted that the Convention on Human Rights and Biomedicine has been only signed by Ukraine but not ratified.

According to Part 4 of Art. 284 of the Civil Code of Ukraine (hereinafter - the CC of Ukraine), an adult capable natural person who is aware of the importance of his or her actions and can manage them, has the right to refuse treatment. In Part 4 of Art. 43 of the Fundamentals provide that a patient who has acquired full civil capacity and is aware of the importance of his or her actions and can manage them has the right to refuse treatment. In contrast to the right of refusal, a guarantee for the preservation of life in Part 5 of Art. 284 of the CC of Ukraine and Part 2 of Art. 43 of the Fundamentals states the following: in urgent cases, in the presence of a real threat to the life of an individual, medical care is provided without the consent of the individual or his or her legal guardians. The ECtHR judgment on Jehovah's Witnesses of Moscow and Others v. Russia (2010) ${ }^{15}$ states that the very essence of the Convention is respect for human dignity and freedom, and the notion of selfdetermination and personal autonomy are important principles underlying the interpretation of guarantees of their observance. The ability to pursue such a lifestyle chosen by the citizen at his or her own will implies the possibility of pursuing activities that are perceived as harmful or dangerous to the health (physical condition) of that citizen. In the case of refusal of medical care, even in cases where the refusal of a particular method of treatment can lead to death, the compulsory treatment, without the consent of a capable, adult patient, is an interference with his / her right to personal inviolability and infringement of the rights guaranteed Art. 8 of the Convention. The freedom to agree to or refuse a particular treatment

${ }^{14}$ Convention for the Protection of Human Rights and Dignity of the Human Being with regard to the Application of Biology and Medicine: Convention on Human Rights and Biomedicine as of 04.04.1997. signed by Ukraine on 22.03.2002). URL: https://zakon.rada.gov.ua/laws/ show/994_334.

${ }^{15}$ ECtHR judgment in the case of "Jehovah's Witnesses of Moscow and others v. Russia” as of 10.06.2010. URL: http://hudoc.echr.coe.int/eng?i=001-99221. 
or to choose an alternative treatment is of primary importance for the principles of self-determination and personal autonomy. However, to preserve the meaning of such freedom, the patient shall have the right to make decisions by their views and values, which would seem irrational, unreasonable and short-sighted to other people. Freedom of choice and self-determination are fundamental components of life, and in the absence of any indication of the need to protect third parties, for example, through forced vaccination of the population during an epidemic, the state should refrain from interfering with the freedom of choice of citizens in matters of health care, since intervention can only reduce, not increase, vital values.

In the case of Arskaya v. Ukraine (2014) ${ }^{16}$, the ECtHR stated that the freedom to agree or refuse assigned treatment is an extremely important principle of self-determination and personal independence. In the field of medical care, refusal of certain treatment may inevitably lead to death, but the imposition of treatment without the consent of a mentally healthy adult is a neglect of the physical integrity of the person in such a way that it may violate the rights enshrined in paragraph 1 of Art. 8 of the Convention. In the case of Glass v. The United Kingdom (2004) ${ }^{17}$, the ECtHR noted that the dispute between the applicants and the hospital staff had to be referred to the courts and that the treating physicians of the applicant were mistaken in that they were faced with an emergency. The ECtHR considers that these issues should be dealt with in the light of Paragraph 2 of Article 8 of the Convention concerning the "necessity" of interference, not in terms of the requirement to intervene "by law". The ECtHR considers that the measure taken by the hospital staff was intended, in the clinical opinion, to protect the applicant's interests. In this regard, the ECtHR recalls that in its interim decision as of March 18, 2003, on the admissibility of the application, it rejected any suggestion under Art. 2 of the Convention, stating that doctors intended to unilaterally speed up the death of the applicant either by administering diamorphine to him or by inserting a DNR into his medical card. Given of the circumstances of the case, the ECtHR considers that the decision of the authorities to disregard the applicant's objection to the proposed medical measure, in the absence of appropriate judicial authorization, led to a violation of Art. 8 of the Convention. However, the Court notes, as in its decree on the admissibility of the statement, that such an order only excluded the use of vigorous heart

\footnotetext{
${ }^{16}$ ECtHR judgment in the case of “Arskaya v. Ukraine” as of 05.03.2014. URL: http://hudoc.echr.coe.int/eng?i=001-138590.

${ }^{17}$ ECtHR judgment in the case of "Glass v. The United Kingdom" as of 09.03.2004. URL: http://hudoc.echr.coe.int/eng?i=001-61663.
} 
massage and intensive respiratory support, but did not preclude the use of other means, such as oxygenation, to support the applicant's life.

In this segment of the research national jurisprudence cannot be ignored, namely the judgment of the Lipovodolynskyi district court of Sumy region as of 14.11 .2018 , case № $581 / 625 / 18^{18}$, which decided to oblige the Lipovodolinsky central district hospital to accept the refusal of PERSON_2 from any medical interventions by the medical staff of this institution, except in urgent cases, in the presence of a real threat to the life of the individual (the plaintiff in the case), as well as the inability to obtain for objective reasons consent to such intervention. PERSON_2 filed a lawsuit stating that on August 13, 2018, he had appealed to the Lipovodolynskyi district hospital to refuse any medical interventions without his consent, but the defendant denied him the exercise of his right to refuse medical interventions. Defending his position, in particular, the plaintiff stated that it was the duty of doctors to provide all patients and persons seeking medical care with appropriate medical services while explaining the consequences of not applying one or the other treatment or diagnostic methods. In cases where the condition of the individual threatens his life or he becomes unconscious due to another painful condition, in such cases the consent of the person to medical interventions is not obtained and the necessary medical assistance is provided immediately. We support the ECtHR's position in Arskaya v. Ukraine: The ECtHR considers that the issue of the legal significance of refusing $\mathrm{S}$. to vital treatment needed to be addressed at the appropriate time, namely when medical staff refrained from offering the treatment offered under the patient's decision. Therefore, according to national law, the decision to refuse at the moment of exercising the right of refusal appears correct ${ }^{19}$.

\section{The balance of private and public interests}

Another balance that seems to be interesting for the Ukrainian legal system is the balance of private and public interests. Taking into consideration the dispersion of each of the interests a balance in the

\footnotetext{
${ }^{18}$ Рішення Липоводолинського районного суду Сумської області від 14.11.2018 р. (справа № 581/625/18). URL: http://reyestr.court.gov.ua/Review/77899139 (Rishennya Lypovodolyns'koho rayonnoho sudu Sums'koyi oblasti vid 14.11.2018 r. (sprava № 581/625/18).

19 Сенюта I.Я. Право людини на медичну допомогу та свобода. URL: https://www.academia.edu/39343553/\%D0\%9F\%D0\%A0\%D0\%90\%D0\%92\%D0\%9E_\%D0\% 9B\%D0\%AE\%D0\%94\%D0\%98\%D0\%9D\%D0\%98_\%D0\%9D\%D0\%90_\%D0\%9C\%D0\%95\% D0\%94\%D0\%98\%D0\%A7\%D0\%9D\%D0\%A3_\%D0\%94\%D0\%9E\%D0\%9F\%D0\%9E\%D0\% 9C\%D0\%9E\%D0\%93\%D0\%A3_\%D0\%A2\%D0\%90_\%D0\%A1\%D0\%92\%D0\%9E\%D0\%91\% D0\%9E\%D0\%94\%D0\%90 (Senyuta I.YA. Pravo lyudyny na medychnu dopomohu ta svoboda).
} 
researched area can be found. Under the general principles of medical ethics and deontology, which are fully consistent with the Hippocratic Oath, the patient's right to confidentiality must prevail over all other interests. However, there is an opinion in the scientific literature that in modern conditions this statement is a fiction ${ }^{20}$. The particularities of balancing the private interests of a certain person with public ones can be illustrated by ECtHR judgments listed below.

In the case of Z. v. Finland (1997) ${ }^{21}$, ECtHR outlines, in particular, that on September 23, 1992, Senior Doctor L. lodged a complaint with the Parliamentary Ombudsman against a court order requiring him to testify. In the Opinion as of February 5 1993, the Parliamentary Ombudsman expressed the view that national law had not been violated and the city court. The court, while investigating the crime, had duly balanced the public interest and the applicant's right to maintain medical secrecy. The ECtHR considers that protecting personal information, not just medical information, is extremely important for a person to exercise his or her right to respect for privacy and family life, as guaranteed by Art. 8 of the Convention. Respect for the confidentiality of one's health information is an integral principle of the legal systems of the States Parties to the Convention. Not only the respect for the patient's medical secrecy is decisive, but also his or her confidence in the medical profession and medical services in general. Therefore, domestic law shall provide guarantees sufficient to prevent the transmission or disclosure of medical secrecy, which may be contrary to the provisions of Art. 8 of the Convention (see $\S$ c, Art. 3, 5, 6 and 9 of the 1981 Convention for the Protection of Individuals with regard to Automatic Processing of Personal Data). The ECtHR points out that the considerations outlined above are particularly important when it comes to non-disclosure of information regarding a person's HIV illness since disclosure of such information can significantly affect a person's private and family life, social status, and employment, putting such a person at risk of becoming an exile in society. Therefore, an interest in the confidentiality of such information will be of greater importance in determining whether interference with the exercise of this right is consistent with the purpose of the law being prosecuted. Such interference cannot be recognized as necessary under with Art. 8 of the Convention unless it is justified by certain overriding public interests.

\footnotetext{
${ }^{20}$ J. Payne-James, I. Wall, P. Dean. Medicolegal Essentials in Healthcare. $2^{\text {nd }}$ edition Cambridge University Press, 26.11.200. 284 p.

${ }^{21}$ ECtHR judgment in the case of “Z. v. Finland” as of 28.02.1997. URL: http://hudoc.echr.coe.int/eng?i=001-58033.
} 
At the same time, the ECtHR recognizes that the interests of the investigation of the crime and the publicity of the trial may outweigh the interests of both the patient and the public as a whole in relation to the non-disclosure of medical secrecy (see Article 9 of the 1981 Convention, which states that such interests (in crime investigations) are even more important).

In the judgment of Avilkina and Others v. Russia (2013) ${ }^{22}$, the ECtHR reiterated that maintaining the confidentiality of health data is crucial not only to protect the privacy of the patient but also to maintain his or her confidence in health professionals and the health care system as a whole. In the absence of such safeguards, those in need of medical assistance may refrain from seeking the necessary treatment, thereby endangering their health. However, the interests of patients and the public as a whole in protecting the confidentiality of medical information may be outweighed by the interests of investigating and punishing crimes, as well as ensuring the transparency of judicial proceedings, if such interests are proven to be of greater importance. The ECtHR also recalls that, in dealing with personal data transfers, it acknowledged that the competent public authorities should retain some discretion regarding the establishment of a fair balance between relevant public and private interests, which conflict with each other. However, such discretion is accompanied by European supervision. Referring to the unlimited powers of the prosecutor's office to request information that constitutes medical secrecy, the courts found it legitimate to transmit such information and refused to satisfy the applicants' claim. The ECtHR does not see in the text of the court rulings any indication that the national authorities have tried to strike a fair balance between the applicants' right to respect for their private lives and the activities of the prosecutor's office aimed at protecting public health and the rights of citizens in this area. The ECtHR also supported its position in the case of Sidorova v. Russia (2019) ${ }^{23}$ mainly, the provision that the protection of personal data, including medical information, is fundamental to a person's right to respect for his or her private and family life, guaranteed Art. 8 of the Convention. However, the interests of the patient and the public at large in protecting the confidentiality of medical data may be outweighed by the interests of the investigation and the publicity of the trial if such interests are proven to be of greater

\footnotetext{
${ }^{22}$ ECtHR judgment in the case of "Avilkina and Others v. Russia” as of 07.10.2013. URL: http://hudoc.echr.coe.int/eng?i=001-120071.

${ }^{23}$ ECtHR judgment in the case of "Sidorova v. Russia" as of 28.05.2019. URL: http://hudoc.echr.coe.int/eng?i=001-193260/
} 
importance. The ECtHR also recalls that in matters relating to the disclosure of personal data, as it has already stated in other cases, competent national authorities should have some discretion to strike a fair balance between relevant conflicting public and private interests. However, such discretion implies scrutiny by the relevant European bodies, and the limits of such discretion shall depend on such factors as the nature and importance of the interests at stake and the degree of intervention. The Court notes that the applicant was neither a suspect nor a defendant in any criminal proceedings. The Government also failed to adduce any evidence regarding any administrative investigation into the complaint against the applicant. Given the material submitted, the Court did not see any urgent public need to require the applicant's confidential medical information to be disclosed.

National jurisprudence on balancing private and public interests is in line with the ECtHR's case law. In the Resolution of the Kupyanskyi City District Court of Kharkiv region as of May 31, 2017, case no. $678 / 1177 / 17^{24}$, it was found that the investigator of the Kupyanskyi police department PERSON_3 had filed a request to the Chief Doctor of Kupyanskyi Central City Hospital on the PERSON_2 being registered as psychiatric patient in connection with the need to investigate criminal proceedings №. 1201522037000270 for ref. № 85/1046 of 20.01.2016 ... Based on the above, the court considered that the evidence to confirm the guilt of PERSON_5 in the commission of the said offense, is absent, as is the absence of the composition of the offense, and therefore the administrative proceedings against PERSON_1 under Art. 188-39 Part 4 of the Code of Administrative Offenses shall be closed in the absence of the offense in his actions. In the Resolution of the Communarskyi District Court of Zaporizhzhia as of October 13, 2016, the case No. 333/4999/16- ${ }^{25}$ the judge finds it to be established that PERSON_2, being an official of the controller of personal data, in the absence of data on the conduct of pre-trial investigation trial of PERSON_4, gave unauthorized person information about the mental health of the latter, which did not comply with the procedure for protection of personal data established by the law on protection of personal data, which led to illegal access to the said data by unauthorized persons and to the violations

\footnotetext{
${ }^{24}$ Постанова Куп'янського міськрайонного суду Харківської області від 31.05 .2017 p. (справа № 628/1177/17). URL: http://reyestr.court.gov.ua/Review/66866596 (Postanova Kup’yans'koho mis'krayonnoho sudu Kharkivs'koyi oblasti vid 31.05.2017 r. (sprava № 628/1177/17).

25 Постанова Комунарського районного суду м. Запоріжжя від 13.10 .2016 p. (справа № 333/4999/16-п). URL: http://reyestr.court.gov.ua/Review/62006490 (Postanova Komunars'koho rayonnoho sudu m. Zaporizhzhia vid 13.10.2016 r. (sprava № 333/4999/16-p).
} 
of personal data rights, namely those of PERSON_4. While analyzing both judgments of national courts, it can be noted that the criteria for balancing the interests, in particular are: 1) the existence of rights of a competent person, which is caused, for example, by the investigation of criminal proceedings against an individual, the data on whom is required; 2) using such a measure to secure criminal proceedings as temporary access to personal belongings and documents, if necessary, to read them, to make copies and to obtain them (to seize them), remembering that, as a rule, in the researched field, personal belongings and documents may contain medical confidential information.

Witness immunity is important in the research of this balance. In the new wording of the Civil Procedure Code of Ukraine (hereinafter - the CPC of Ukraine) (Article 70), persons who are legally obliged to keep confidential information entrusted with confidentiality are excluded from the list subjects who cannot be questioned as witnesses about such information in connection with their professional or professional status. Previously, health professionals and other employees of the healthcare sector (for example, management and employees of health departments) were on that list. The issue of witness immunity is closely linked to a person's right to medical secrecy. Criminal Procedure Code of Ukraine (para. 2 h. 2, art. 65) provides clearer regulations with appropriate guarantees of human rights. It contains the provision, which health care professionals and other persons who became aware of illness, medical examination and its results, intimate and family aspects of a person's life, in connection with the performance of professional or official services, cannot be questioned as witnesses about the information that is a medical secret. Only a person, who has entrusted to the above persons the information which contains medical secret, can exempt them from the obligation to perform such professional duty. The amount of information that can be lawfully disclosed is also determined by the person who provided it, i.e. the patient or his or her legal representative. It should be emphasized that the procedure for such exemption is stipulated by law, and it can be provided namely as a written statement of will signed by the person who entrusted the said information. Unfortunately, nowadays the CPC of Ukraine not only did not improve the previous version of Art. 51 of the CPC of Ukraine (effective until amended), but and generally excluded from the list of persons who cannot be interrogated as witnesses, those who are obliged to keep medical secrecy, thereby endangering human rights, in particular, the rights guaranteed by Art. 8 of the Convention. 
It is necessary to draw attention to the case law, which actualizes the issue of preserving information that contains medical secret by medical professionals in the context of administration of justice. The judgment of the Kyiv Court of Appeal within the panel of judges of the Civil Trial Chamber as of 11.04.2019, case No 761 / 29995/17, made as a result of the claim of PERSON_2 to PERSON_4, State Institution "National Scientific Center 'Institute of Cardiology named after Academician M.D. Strazheska' of the NAMS of Ukraine” on the recognition of decisions and actions as illegal, compensation for moral damage. In particular, PERSON_2 indicates that on March 7, 2017, a leading researcher of the department of interventional cardiology of the State Institution "National Scientific Center 'Institute of Cardiology named after Academician M.D. Strazheska' of the NAMS of Ukraine” PERSON_4 (as the chairman of the commission that conducted his examination on March 04, 2017), while providing testimony in the courtroom of the Solomianskyi District Court of Kyiv, disclosed information that contained medical secret about PERSON_2, without his permission. PERSON_4 disclosed the above information to an unspecified number of persons, as there were media representatives in the courtroom, as well as an online broadcast of the court hearing was conducted, and it can be assumed that a lot of people in Ukraine and abroad were watching it. Such actions by a PERSON_4 violated PERSON's_2 rights to life, healthcare and medical secrecy, causing undue harm to his business reputation, honor and dignity. Thus, the doctor PERSON_4 violated Art. 32, 34 of the Constitution of Ukraine, Part 1 Article 286 of the Civil Code of Ukraine, Art. 39-1 Fundamentals of the Legislation of Ukraine on Health, Article 11 of the Law of Ukraine "On Information” when he dislosed PERSON's_2 medical secret. PERSON_2 requested the court to declare actions of PERSON_4, mainly the disclosure of doctor's and medical secrets regarding PERSON_2 on March 7, 2017, while giving evidence as a witness in the courtroom as illegal and to withdraw from leading researcher of the department of interventional cardiology of the "National Scientific Center 'Institute of Cardiology named after Academician M.D. Strazheska' of the NAMS of Ukraine” PERSON_4 in favor of PERSON_2 UAH 1000000 , as compensation for moral harm caused by the disclosure of medical secret. The panel of judges of the Court of Appeal, taking into account the provisions of the current legislation of Ukraine, promulgation by the mass media clarified opinion of the State Institution "National Scientific Center 'Institute of Cardiology named after Academician M.D. Strazheska' of the NAMS of Ukraine" concerning the state of health of the PERSON_2, provided by the authorized person with the written consent of PERSON_2 
for the disclosure of his personal data, agrees with the findings of the court of first instance that when giving evidence, as a witness, in the in the courtroom of Solomianskyi District Court of Kyiv, PERSON_4 did not violate the law regarding the prohibition of disclosure of doctor's and medical secret as regards to PERSON_2 $2^{26}$.

The above judgment clearly indicates, on the one hand, the importance of the topic, and, on the other, the problems with law implementation and enforcement. According to the results of the analysis of the legal framework with the projection on the outlined resolution, in particular, several remarks can be made: 1 ) the procedure for the release of medical professionals from the obligation to preserve medical secret is clearly defined in Part 2, Article 3. 65 of the Criminal Procedure Code of Ukraine, and therefore, in extrapolation to this case there should have been a written consent of PERSON_2 that he does not object to the disclosure of his personal data for the forensic examination, as well as to conduct the examination itself. Therefore, it seems strange to have such an expansive interpretation of the court, since the consent concerned the forensic examination and not the medical professionals; 2) the provision of information to the mass media is not a statutory requirement for the release of a healthcare professional from the obligation of keeping professional secrecy.

The ECtHR's position in Z. v. Finland ${ }^{27}$ case seems to be similar to the above statements. The Court outlines: "[t]he Finnish law provides that the applicant's medical advisers could be obliged to testify about the applicant without her consent only in very limited number of cases, namely in the case of the investigation, prosecution of committing crimes punishable by imprisonment for a term not less than six years (see paragraph 46). Since they refused to give evidence to the police, the latter had to obtain a sanction from a judicial authority, a city court, to hear them as witnesses (see paragraph 28). ... The persons involved in this process were obliged to consider this information confidential and non-disclosable... It should not be doubted that the authorized state bodies were given the right to believe that the public interest testified in favor of the investigation and prosecution of $\mathrm{X}$., who had made attempts to kill as regards to five crimes, not just three of them". Thus, the ECtHR, establishing a balance, indicates that, subject to a statutory regulation, public interest may prevail without violating human rights.

\footnotetext{
${ }^{26}$ Постанова Київського апеляційного суду від 11.04.2019 р. (справа № 761/29995/17). URL: http://reyestr.court.gov.ua/Review/81170220.

${ }^{27}$ ECtHR judgment in the case of “Z. v. Finland” as of 25.01.1997. URL: http://hudoc.echr.coe.int/ eng?i=001-145423.
} 


\section{CONCLUSIONS}

There is an urgent need to eliminate the discrepancy between the bylaws, in particular, MOH Order 1269, and the laws of Ukraine, to observe in the course of right enforcement the balance of the stated interests in order to respect human rights, as well as to ratify the Convention on Human Rights and Biomedicine, which contains many up-to-date progressive provisions and may have a positive impact on expanding and improving the content and scope of personal non-proprietary human rights in healthcare.

It is also necessary to amend Art. 70 CPC of Ukraine, in order to include medical professionals and other persons working in the field of health care to the list of subjects of witness immunity, as well as to regulate the procedure for the release of medical professionals from maintaining the professional duty of medical secrecy in the event of the death of their patient, which is not legally defined today either in criminal or in civil proceedings.

The analysis of balances in health care is aimed at achieving the key balance: the balance of interests of the health care professional and the interests of the patient, which consists in the ratio of those interests where each of the parties of legal relations in the provision of health care does not violate the subjective rights of the other party and can freely determine their actions to achieve the goal (results), which is to preserve life and health, strengthen and restore health, establish the absence of diseases in compliance with the statutory regulations of Ukraine.

\section{SUMMARY}

The article deals with the issues of human right balances in the field of healthcare. Thus, while analyzing the jurisprudence of the European Court of Human Rights, the authors highlight balancing such pairs of legal interests as patient's right to life and the right to respect of private life; private and public interests. The named issues are of significant importance in modern society.

Medical law is a branch of law that combines such important aspects of social wellbeing as law, medicine, ethics, etc. These aspects can collide and create the synergistic value of parallels. European Court of Human Rights, being the custodian of the rule of law, constantly seeks balances to ensure human rights and to develop the concept of humanity as any human rights activity. While weighting rights and legitimate interests, the balance of justice shall be maintained. 
There is an urgent need to eliminate the discrepancy between the bylaws, in particular, MoH Order No. 1269, and the laws of Ukraine; to amend Art. 70 of the CPC of Ukraine, having secured among the subjects of witness immunity medical professionals and other persons working in the field of healthcare; to observe during the law implementation and enforcement the balance of the above interests in order to respect human rights; to ratify the Convention on Human Rights and biomedicine, which contains many time-consuming progressive institutions and would have a positive impact on expanding and improving the content and scope of personal non-proprietary human rights in healthcare. The analysis of balances in healthcare is aimed at achieving the key balance: that of interests of the healthcare professional and patient, which consists in the ratio of those interests in which each of the parties in the healthcare relationships would not violate the subjective rights of the other party and exercise freely and determine their actions to achieve the goal, which is to preserve life and health, strengthen and restore health, establish the absence of diseases in compliance with the statutory regulations of Ukraine.

\section{REFERENCES}

1. P.G. Carozza, Human Dignity, [in:] D. Shelton (ed.), The Oxford Handbook of International Human Rights Law, Oxford 2015, pp. 345-359.

2. V. Horodovenko, V. Pashkov, L. Udovyka, Protection of Patients' Rights in the European Court of Human Rights, Wiadomości Lekarskie, 2018/06. Available at: http://wl.medlist.org/06-2018-13/.

3. Kapelańska-Pręgowska J. European court of human rights ( $\mathrm{gc})$, case of lambert and others v. France, judgment of 5 june 2015, application NO. 46043/14. Comparative Law Review, [S.l.], v. 21, p. 157-174, feb. 2017. ISSN 0866-9449. Available at: <https://apcz.umk.pl/ czasopisma/index.php/CLR/article/view/CLR.2016.005/10962>. Date accessed: 07 Sep. 2019. doi:http://dx.doi.org/10.12775/CLR.2016.005.

4. S. Matthew, The European Court of Human Rights Margin of Appreciation and the Processes of National Parliaments, Human Rights Law Review 2015, vol. 15, no. 4, pp. 745-774.

5. Convention for the protection of human rights and fundamental freedoms as of 04.11.1950 (ratified by Ukraine on 17.07.1997). URL: https://zakon.rada.gov.ua/laws/show/995_004.

6. ECtHR judgment in the case of «Lambert and Others v. France» as of 15.07.2015. URL: http://hudoc.echr.coe.int/eng?i=001-155352. 
7. ECtHR judgment in the case of "Pretty v. United Kingdom" as of 29.04.2002. URL: http://hudoc.echr.coe.int/eng?i=001-60448.

8. Наказ МО3 України «Про затвердження та впровадження медико-технологічних документів зі стандартизації екстреної медичної допомоги» від 05.06.2019 p. № 1269. URL: https://moz.gov.ua/ article/ministry-mandates/nakaz-moz-ukraini-vid-05062019--1269-prozatverdzhennja-ta-vprovadzhennja-mediko-tehnologichnih-dokumentiv-zistandartizacii-ekstrenoi-medichnoi-dopomogi.

9. Convention for the Protection of Human Rights and Dignity of the Human Being with regard to the Application of Biology and Medicine: Convention on Human Rights and Biomedicine as of 04.04.1997. signed by Ukraine on 22.03.2002). URL: https://zakon.rada.gov.ua/laws/ show/994_334.

10.ECtHR judgment in the case of "Jehovah's Witnesses of Moscow and others v. Russia” as of 10.06.2010. URL: http://hudoc.echr.coe.int/ eng?i=001-99221.

11.ECtHR judgment in the case of "Arskaya v. Ukraine" as of 05.03.2014. URL: http://hudoc.echr.coe.int/eng?i=001-138590/

12.ECtHR judgment in the case of "Glass v. The United Kingdom" as of 09.03.2004. URL: http://hudoc.echr.coe.int/eng?i=001-61663.

13. Рішення Липоводолинського районного суду Сумської області від 14.11.2018 p. (справа № 581/625/18). URL: http://reyestr.court.gov.ua/ Review/77899139.

14. Сенюта І.Я. Право людини на медичну допомогу та свобода. URL: https://www.academia.edu/39343553/\%D0\%9F\%D0\%A0\%D0\% 90\%D0\%92\%D0\%9E_\%D0\%9B\%D0\%AE\%D0\%94\%D0\%98\%D0\% 9D\%D0\%98_\%D0\%9D\%D0\%90_\%D0\%9C\%D0\%95\%D0\%94\%D0\% 98\%D0\%A7\%D0\%9D\%D0\%A3_\%D0\%94\%D0\%9E\%D0\%9F\%D0\% 9E\%D0\%9C\%D0\%9E\%D0\%93\%D0\%A3_\%D0\%A2\%D0\%90_\%D0\% A1\%D0\%92\%D0\%9E\%D0\%91\%D0\%9E\%D0\%94\%D0\%90

15. J. Payne-James, I. Wall, P. Dean. Medicolegal Essentials in Healthcare. $2^{\text {nd }}$ edition Cambridge University Press, 26.11.2009. - 284 p.

16. ECtHR judgment in the case of “Z. v. Finland" as of 28.02.1997. URL: http://hudoc.echr.coe.int/eng?i=001-58033.

17.ECtHR judgment in the case of "Avilkina and Others v. Russia" as of 07.10.2013. URL: http://hudoc.echr.coe.int/eng?i=001-120071.

18. ECtHR judgment in the case of "Sidorova v. Russia" as of 28.05.2019. URL: http://hudoc.echr.coe.int/eng?i=001-193260. 
19.Постанова Куп'янського міськрайонного суду Харківської області від 31.05.2017 p. (справа № 628/1177/17). URL: http://reyestr. court.gov.ua/Review/66866596.

20. Постанова Комунарського районного суду м. Запоріжжя від 13.10.2016 р. (справа № 333/4999/16-п). URL: http://reyestr.court.gov.ua/ Review/62006490.

21.Постанова Київського апеляційного суду від 11.04.2019 p. (справа № 761/29995/17). URL: http://reyestr.court.gov.ua/Review/ 81170220

\section{Information about the author:} Senyuta I. Y., Doctor of Laws, Associate Professor, Head of the Department of Medical Law of the Faculty of Post-Graduate Education of Danylo Halytskyi Lviv National Medical University 69, Pekarska str., Lviv, Ukraine 